\title{
ELK RANCH DETERMINATION OF ELIGIBILITY FOR THE National Register of Historic Places
}

\section{MARY M. HUMSTONE $\uparrow$ AMERICAN STUDIES PROGRAM UNIVERSITY OF WYOMING ^ LARAMIE}

\begin{abstract}
$\uparrow \quad$ AbSTRACT
During summer 2010, the University of Wyoming American Studies Program conducted an intensive cultural landscape survey and historical analysis of the Elk Ranch in Grand Teton National Park. Led by Research Scientist Mary Humstone, students documented the ranch landscape and remaining buildings. They conducted research in local archives to uncover the history of the ranch and determine its significance in the history of Jackson Hole and Grand Teton National Park. The team determined that the property is eligible for the National Register of Historic Places, with significance in agriculture and conservation.
\end{abstract}

\section{INTRODUCTION AND METHODOLOGY}

Like all federal agencies, the National Park Service is required by law to survey and evaluate resources under its jurisdiction to determine their historic significance and integrity, and their eligibility for the National Register of Historic Places, the nation's list of properties significant in American history and culture. This report outlines the process used to evaluate the Elk Ranch and the findings of the survey team.

Each building on the Elk Ranch was documented and photographed, and its current condition was recorded. A landscape survey was conducted using the thirteen landscape characteristics prescribed by the "Cultural Landscapes Inventory Professional Procedures Guide" (National Park Service, 1998). The irrigation system was examined and interviews conducted with the current irrigator of the property. The team also participated in a demonstration of current irrigation practices (Figure 1).

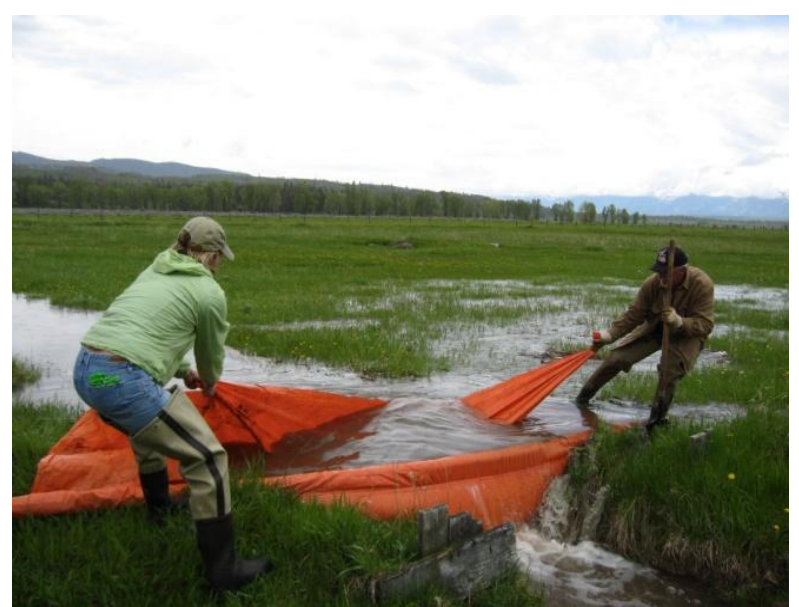

Figure 1. Mary Humstone and Bill Lawrence demonstrate flood irrigation on the Elk Ranch (S. Lowe, 2010)

Archival research was conducted at the University of Wyoming American Heritage Center and the Wyoming State Archives, as well as the archives of Grand Teton National Park and the Jackson Hole Historical Society. In addition, team members had access to research materials from the Rockefeller Archives in Sleepy Hollow, New York, courtesy of a National Park Service intern. Primary materials such as maps, correspondence, newspaper articles and historic photographs were consulted during the research phase, and several informants with first-hand experience of the ranch were interviewed. 


\section{SITE DESCRIPTION}

The Elk Ranch comprises approximately 2,425 acres in the northern section of Grand Teton National Park, near the Moran Entrance Station. The property encompasses lands homesteaded by several early Jackson settlers and later consolidated by rancher Josiah David (Si) Ferrin. Although few ranch buildings remain, the property definitely reads as a ranch, with cattle guards, fences, gates and a corral, barn, implement shed, bunkhouses and shop.

Elk Ranch is located on a broad bench that rises above the Snake and Buffalo Fork Rivers, which form its western and northern boundaries, respectively. The low-lying land near the confluence of the two rivers is marsh land. To the west rise the Teton Mountains, while immediately east of the ranch is evergreen-covered Uhl Hill, where lumber was once harvested for a locally operated sawmill. To the southeast is Mt. Leidy, which along with Spread Creek is the source of much of the water used to irrigate the bench lands. The land is covered with glacially deposited rocks.

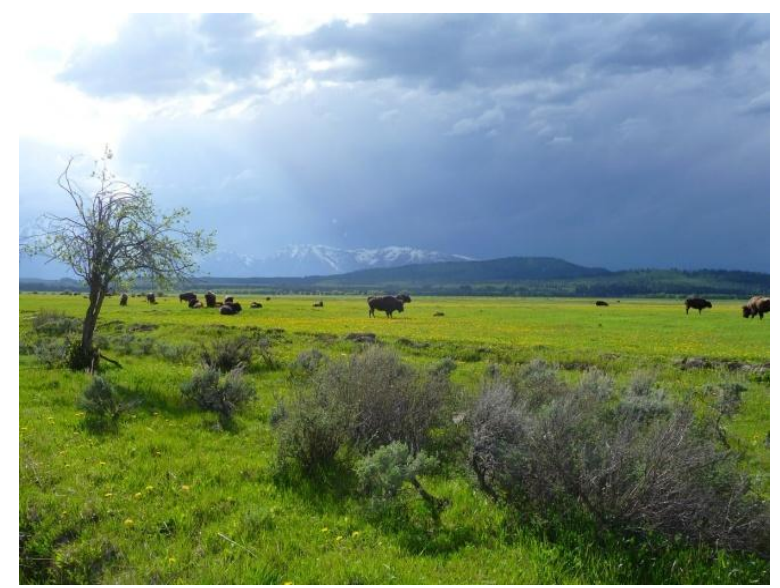

Figure 2. View of irrigated pasture lands on Elk Ranch, looking southwest (M. Humstone, 2010).

Highway 191 bisects the property, dividing it into the non-irrigated sagebrush bench lands to the west and the irrigated bench lands to the east. The irrigated pastures to the east of Highway 191 are fenced for cattle, and are criss-crossed by a complex system of irrigation ditches. The bench lands extend unobstructed to the south, where the southern boundary of the Elk Ranch property is defined by Wolff Ridge (Figure 2).

The Elk Ranch building complex occupies a small area on the flat river bottom in the northeast section of the property. The dwellings (three cabins, foundations of a house) are sited so that the bench to the south protects them from the wind. The work sheds lie north of the dwellings, while the barn and cattle shed lie to the northeast. The corral is directly north of the barn and cattle shed. A spring-fed creek runs south to north through the building complex, to the east of the dwellings, passing by a spring house located at the base of the bench. Between the building complex and the bench to the west, the land shows evidence of hand-dug irrigation ditches, which are no longer in use. While several buildings have been removed from Elk Ranch, including the main ranch house nicknamed "The Bungalow," those that remain provide a focus for the property, and strong evidence of its former use as a cattle ranch. The six extant buildings include three dwellings, a machine shed, a shop (Figure 3), and an L-shaped barn/cattle shed with an attached corral - all practical, vernacular-style buildings designed to facilitate the ranching operation. Structures include a spring house and the ruins of a spring house.

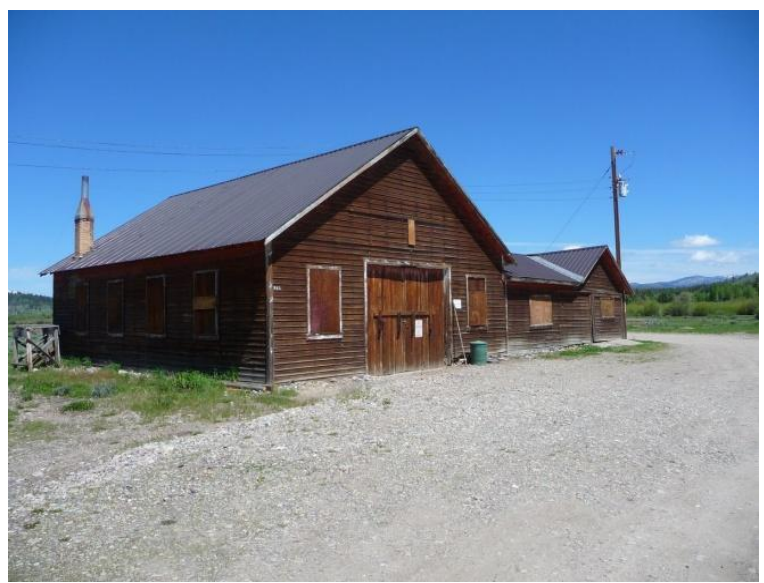

Figure 3. Elk Ranch shop (M. Humstone, 2010).

Prior to the construction of Highway 191 (ca. 1950), the main route through what is now Grand Teton National Park was a county road which ran east of and roughly parallel to the current highway. This was the only road east of the Snake River and an important route for anyone traveling to the north end of the Jackson Hole Valley. This road ran directly through the Elk Ranch, just east of the building complex, and continued north to a bridge over the Buffalo Fork River and on to Moran, where the Snake River Land Company had its headquarters. A section of this graveled county road, from Elk Ranch south to the Wolff Ranch, is still in use but is interrupted by irrigation ditches at several points. Other parts of the former road have been abandoned.

One of the most prominent features on the Elk Ranch is the complex irrigation system, started 
even before permanent settlement of the area. An 1897 map shows the Wolff Ditch as well as several smaller irrigation ditches leading off the Wolff Ditch. The irrigation system, which consists of a series of ditches dug into the rocky soil, was expanded over the next 40 years with water diverted from small creeks and springs throughout the Elk Ranch property. Uhl Reservoir (also called Elk Ranch Reservoir) was built in 1940 to capture more water for irrigation, mainly from snow melting off of Mt. Leidy and diverted from Spread Creek. The ditch system was once dotted with wooden head gates, many of which were later replaced with concrete and metal head gates, still in use today (Figure 4). Although some of the ditches at the north end of the property have been abandoned and many of the original wooden headgates are no longer extant, the majority of the system is maintained and still in use. The complex system of irrigation makes the Elk Ranch pastures stand out in contrast to the natural, sage-covered landscape of the Jackson Hole valley (Figure 2).

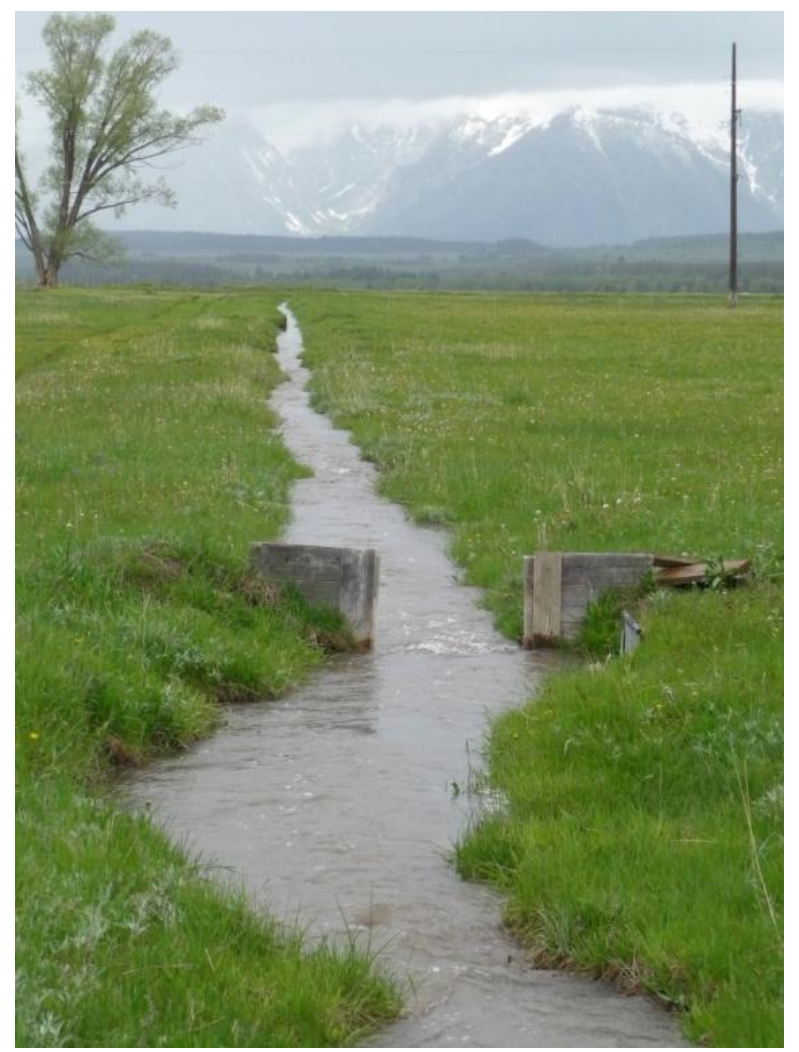

Figure 4. Ditch on Elk Ranch, looking west, showing remains of an original wooden headgate (M. Humstone, 2010)

The Elk Ranch contains small-scale features typical of ranching operations, such as fences, gates, cattle guards and old machinery as well as the irrigation featured described above. Wood post-and- rail and wire fence separates the ranch property from the highway on both sides, and buck-and-rail fence runs sporadically along the north side of the entry lane, continuing east to the bench. Gates are positioned at the entrance from Highway 191, about $1 / 4$ mile east of the entrance, and east of the creek, where historic photographs indicate a large gate, with the words "Elk Ranch" at the top.

\section{$\uparrow \quad$ BACKGROUND HISTORY}

Jackson Hole was settled later than much of the West, due to its isolated location surrounded by mountains and far from major trails and railroad lines, and its high altitude and inhospitable climate. The first permanent Euro-American residents settled in the valley in the mid-1880s; by 1900 almost 700 people resided in the valley, most of them Mormon farmers who migrated north from the Salt Lake City area. Settlers took advantage of the Homestead Act of 1862 and other federal land programs that encouraged settlement of the West. The land in the Jackson Hole valley was difficult to cultivate, and settlers soon found that it was best suited for grazing cattle and raising hay, rather than farming.

The early homesteaders were mostly concentrated in the area east of the Snake River and north of the Gros Ventre River, known as Antelope Flats (or Mormon Row), the Buffalo Fork-Spread Creek area (where Elk Ranch is located), and the valley west of the Snake River. Sagebrush, willows and aspen were plentiful and the glacially deposited soils were covered with quartzite rocks, making plowing difficult. Clearing the land was a slow process, and many homesteaders found that it was difficult to clear more than 10 acres per year.

\section{Homesteading Period}

The property comprising the Elk Ranch headquarters was originally homesteaded by Otto Kusche (probably of German origin) in 1909. Like his fellow homesteaders, Kusche cleared the land of sagebrush by grubbing, plowed it and planted alfalfa. Kusche's land contained a spring which he could use for irrigation, and in 1913 he was granted a permit to build a ditch. He built a house, barn, storeroom and cellar, none of which survives today.

In 1916, Kusche sold his 320-acre homestead to D.E. Skinner, a Seattle ship builder who was one of just a few outside entrepreneurs who tried to establish large cattle ranches in the Jackson Hole valley in the early $20^{\text {th }}$ century. Skinner made the Kusche homestead into the center of his operation, 
which he called Elk Ranch, and which also included land he purchased from other homesteaders. He expanded his operation from 450 cattle to 2,000, before selling the Elk Ranch to Josiah David ("Si") Ferrin in 1919.

Si Ferrin had originally homesteaded south of the Kusche homestead on the Buffalo Bench in 1908. The Elk Ranch was among the many local ranches purchased by Ferrin in the process of building up his land holdings and cattle herd. Ferrin's sons also filed on their own homesteads, using the Homestead Act and later the Stock-Raising Homestead Act of 1916, which liberalized the homesteading regulations, allowing a person to file papers for 640 acres of land "considered suitable only for grazing."

Along with increasing his acreage, Ferrin built up his cattle herd, which numbered about 2,000 head by 1920 and earned him the nickname of "cattle baron of Jackson Hole." Like other ranchers in the valley, Ferrin was involved in several enterprises besides ranching. He served as a hunting guide, supplied beef to the Reclamation Service at the Jackson Lake Dam, hauled freight, cut and hauled timber and operated a sawmill (Daugherty, 1999). He was appointed a state game warden by Governor Bryant B. Brooks in 1918, and served in that capacity for 14 years.

The families who ranched in the Buffalo Fork-Spread Creek area relied on raising hay for their livestock. They drove the cattle to Togwotee Pass in May and brought them back to their ranches in late October or early November, where they were fed on the hay grown during the summer. Most ranching operations would not have been possible without the availability of grazing on public lands while the hay grew on their private lands.

The amount of hay a rancher could grow limited the amount of cattle a ranch could sustain due to the dependence on hay for winter feed. Ferrin's Elk Ranch produced large amounts of hay, the surplus of which he sold to the government to help feed the elk on the National Elk Refuge, which was created in 1914. When it came time to harvest the hay on the Elk Ranch, "it took a 25-man crew and 50 head of horses some 25 working days to get the job done" (Kreps, 2006).

In spite of his productive land, large cattle herd and outside enterprises, Ferrin suffered from the agricultural depression of the 1920s. As early as 1921 Ferrin, along with numerous other ranchers, had met with Horace Albright, the superintendent of Yellowstone National Park, to discuss the possibility of the government purchasing ranchlands - both to protect land from development and to buy out ranchers who could no longer make a living on their land. In 1925, Ferrin and fellow rancher Pierce Cunningham wrote and circulated a petition supporting a buyout of private lands in Jackson Hole. The petition noted that this land could best be used as "a playground" and that such a use would make it "the greatest wealth-producing region of the State." The 97 landowners who signed the petition also pledged the sell their ranches "at what we consider a fair price" (Daugherty, 1999). Considering his early interest in selling out to the government, it is not surprising that Si Ferrin was one of the first Jackson Hole ranchers to sell to J.D. Rockefeller Jr.'s Snake River Land Company (SRLC). When the Ferrins sold their 3,629 acres of land to the SRLC in 1928, Elk Ranch was "the largest outfit in Jackson Hole" (Daugherty, 1999).

\section{Snake River Land Company/Jackson Hole Preserve, Inc., 1929-1950}

As noted above, by the 1920 s it became obvious to the locals that cattle ranching, which had dominated the economy of Jackson Hole for several decades, was becoming economically impractical. At the same time, many locals were discouraged by the type of development that was marring the natural beauty of the valley. In 1923, Yellowstone Park Superintendent Horace Albright, dude rancher Struthers Burt and others devised the Jackson Hole Plan, seeking private funds to purchase lands in Jackson Hole in order to "create a reserve or recreation area that would preserve the 'Old West' character of the valley, or 'a museum on the hoof" (Daugherty, 1999). In 1924, Albright persuaded John D. Rockefeller, Jr. to take a drive from Yellowstone Park to Jackson Hole. Rockefeller's interests in conservation were ignited by this visit, and on a return visit to the area two years later, he decided to finance the Jackson Hole Plan, setting up the Snake River Land Company to purchase property for eventual donation to the National Park Service.

The Snake River Land Company (SRLC) was formed in 1927, and started buying up homesteads in the valley the following year, for eventual donation to the National Park Service for expansion of Grand Teton National Park. However, because the government did not immediately accept the lands, SRLC faced possible loss of the water rights that ran with the land they were purchasing. Therefore, in order to hold the water rights, the SRLC 
decided to maintain irrigation systems on their lands, and to lease some lands for grazing, cultivation and dude ranching.

Raising hay on SRLC lands provided another benefit as well - providing feed for the elk that wintered in the Jackson valley and were important in the development of a "museum on the hoof." Elk Ranch, with its well developed irrigation system, acres of productive hayfields and proximity to the SRLC headquarters (near present-day Moran) was the ideal choice for an agricultural operations center for the SRLC. The company hired a business manager and a foreman Jim Chambers to run the ranch. As Harold Fabian, Vice-President of the SRLC wrote, "At the time it was purchased, [SRLC president] Mr. Webb and I determined its potential importance to the project required its rehabilitation and operation. It has been so well managed . . . that it has borne a substantial part of the carrying costs of the entire project (United States Department of Interior, 1955)". Pastures were leased for grazing cattle, and hay was raised in the irrigated hay meadows. During the winter, cattle were fed hay on site. Thus the Elk Ranch lands were in continuous use for grazing cattle and cutting hay during this period.

By 1940, when the Rockefellers formed the Jackson Hole Preserve, Inc. (JHPI), the Elk Ranch had been well established as the center of operations for the SRLC (Righter, 1983). That year, the company made extensive investments to improve the buildings and the irrigation system. New buildings were constructed and existing buildings given new roofs and siding. Uhl Reservoir was built to increase the water available for irrigation.

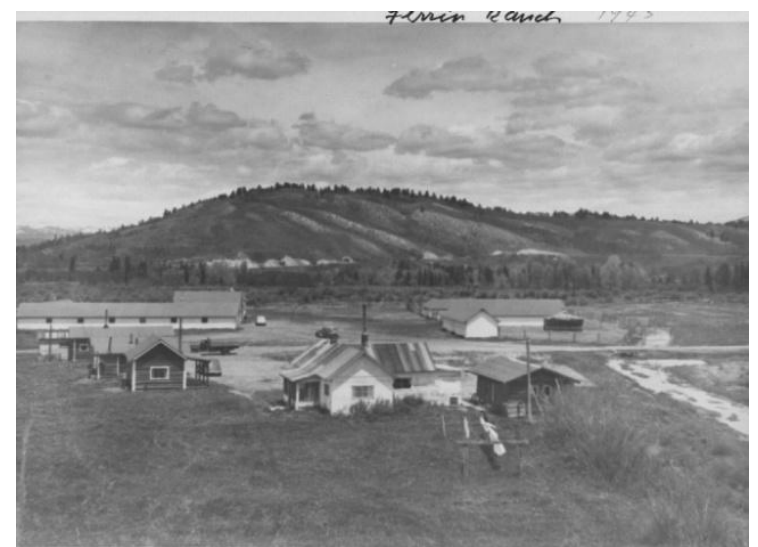

Figure 5. Elk Ranch (Ferrin Ranch), 1943 (Grand Teton National Park archives).

As the SRLC/JHPI project developed, Elk Ranch increased in importance, for both its agricultural and its historical assets. As Fabian outlined in 1955(United States Department of Interior, 1955), the Elk Ranch was in a position to provide hay for the proposed Jackson Hole Wildlife Park near Moran, as well as for migratory game herds. It could provide feed and a wintering place for the substantial herd of horses that would be needed for proposed dude ranches, and could also provide meat and dairy products for the dude ranch and lodge facilities being developed in Grand Teton National Park. In addition, as one of the oldest and most profitable ranches in Jackson Hole, and one of the finest hay ranches, Elk Ranch exemplified the working cattle ranch that was so important to J.D. Rockefeller Jr.'s vision of the expanded Grand Teton National Park. Although large-scale cattle ranching was fairly short-lived in Jackson Hole, its impact on the culture of northwest Wyoming was evident in Rockefeller's time, as it is today. Rockefeller made clear his intention to retain Elk Ranch as a working cattle ranch, as a way of "perpetuating the picturesque features of Jackson Hole as a cattle country" (Righter, 1983).

The Elk Ranch was also a major player in negotiations over cattle grazing and raising hay for winter feeding of elk. When President Roosevelt established the Jackson Hole National Monument (March 1943) to protect the land that Rockefeller had purchased but had not been successful in donating to the government, agreements were made with local ranchers to continue grazing rights within the boundaries of the monument. As of March 1943, several ranchers ran hundreds of cattle on monument lands. In order to honor those leases, the SRLC/JHPI (and later the National Park Service) needed a headquarters for the cattle leasing operations, as well as pasture for cattle, and the Elk Ranch provided both.

The SRLC/JHPI also had an interest in providing hay for the National Elk Refuge in Jackson. The U. S. Fish and Wildlife Service had hoped to get the Elk Ranch property for their own use, and without it, threatened to reduce the number of elk in the Jackson herd due to a shortage of winter feed. Many, including National Park Service director Newton B. Drury, felt that elk should be a priority of the park and favored eliminating cattle ranches and grazing rights altogether and returning the land to a natural state. SRLC/JHPI shared the goal of preserving wildlife, although not if it meant the exclusion of cattle grazing. By providing hay to the National Elk Refuge, the SRLC/JHPI could retain its ranching lands and help preserve the elk herd. In 1947 JHPI signed a contract with the Fish and Wildlife Service and the Wyoming Game 
Commission to sell 1,000 tons of baled hay to the Elk Refuge. In return, the Fish and Wildlife Service agreed to rent JHPI their hay harvesting equipment (Rockefeller Archives). Thus the JHPI continued the tradition started by Si Ferrin of selling a portion of the hay raised at the Elk Ranch to the Elk Refuge.

When the SRLC purchased Elk Ranch from Si Ferrin, they converted the Ferrin building complex for housing the ranch foreman and seasonal workers, and as a general maintenance yard. Historic documents indicate that the Ferrin house, wood shed and a bunkhouse were retained, and an additional four cabins from the Snake River Land Company Headquarters were moved to the site to house workers (ca. 1940. US Dept of Interior 1952). In addition, the company constructed and/or retained several outbuildings for horses, livestock and equipment, including an implement shed, repair shop, blacksmith shop, shed, ice house, harness and grain shed, and three barns, two with attached sheds and corrals (Figures 5, 6).

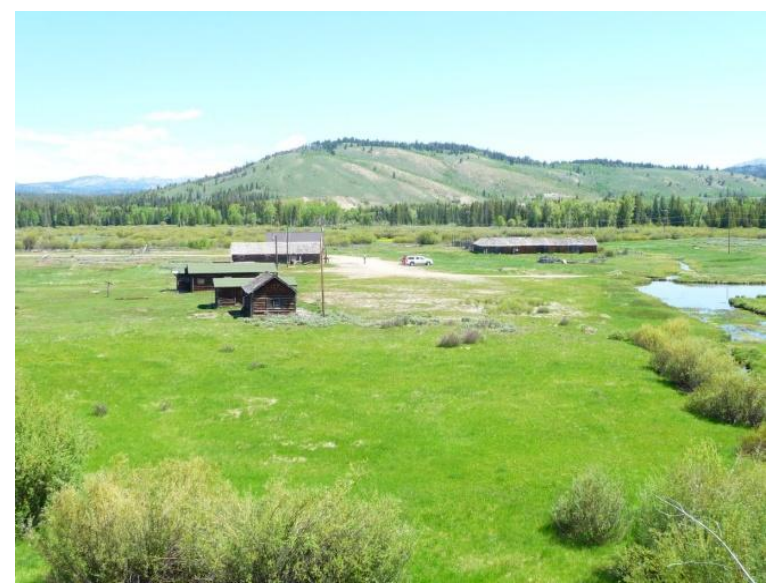

Figure 6. Elk Ranch building complex today (M. Humstone, 2010).

\section{National Park Service. 1950 - present}

In 1950 Congress finally passed an act incorporating the Jackson Hole National Monument into Grand Teton National Park, marking the end of a 23-year struggle to preserve lands outside the original 1929 park boundaries. Although cattle grazing was generally not permitted in national parks, an exception was made in the case of Grand Teton. Section 4 of Public Law 81-787 mandated that the Secretary of the Interior grant each rancher already grazing within the bounds of the park twenty-five years plus the lifetime of a selected heir to continue ranching. Grazing permits, the last to be granted in the park, were granted to 29 ranching families under this Act in 1950.
Over the next several years, the Park Service struggled with how best to balance the grazing rights of local ranchers with the desire to protect natural landscapes and features within the park. As stated in a 1952 summary of the Grand Teton National Park grazing program, "It is . . the policy of the Service to plan for the eventual elimination of the grazing of domestic livestock on the open range within Grand Teton National Park, but with proper regard for the interests of the established grazing permittees, as set forth in Public Law 787" (Grand Teton National Park, Grazing files).

Conservationists favored halting hay production for cattle and elk feed, ceasing cattle grazing, and returning the Elk Ranch to a natural landscape. However, Park Service personnel favored transferring grazing permits from more scenic areas west of the Snake River and north of the Buffalo Fork to fenced pastures on the Elk Ranch and other nearby properties (Grand Teton National Park, General Grazing Files). Because the Elk Ranch had been cultivated for many years, it was considered less pristine than the park's "natural" landscapes. Concentrating the cattle on the Elk Ranch would at least keep all of the "undesirable aspects" of cattle ranching from affecting the entire park (US Dept of Interior, 1955).

In 1957, Grand Teton National Park transferred the grazing permittees from the Potholes/Moran area to the Elk Ranch, for "the protection of natural and scenic values and enhanced recreation values and visitor use" (Jackson Hole Historical Society, Cattle Ranching files). The park continued to transfer cattle away from the west side of the park, to Elk Ranch and other properties east of Highway 191. By 1972, only six permittees remained in the Elk Ranch and Mormon Row areas. The National Park Service maintained the irrigation system for the permittees.

By the 1990s, when many of the permits were expiring, there was a movement among ranchers and conservationists to extend them to help preserve open space outside park boundaries. Ranchers argued that the federal grazing permits were critical to the continued viability of their ranches, and if the permits expired, they might be forced to sell their land for development. Since several of these ranchers owned prime acreages on the edges of the park, conservationists also became alarmed at the prospect of widespread development of these properties. In response to this situation, the Wyoming Congressional delegation authored a bill to 
create an "open space study group" charged with studying "the relationship between park grazing and preserving the valley's open space and 'pastoral' character (Jackson Hole Historical Society, Cattle Ranching file). Members of the delegation expressed their support of grazing in the park, and the law creating the study group provided for permits to be extended until the study was concluded. All of the remaining permittees eventually gave up their grazing permits.

As of 2010, only one rancher is still running cattle on Elk Ranch. Ernie Cockrell of the Pinto Ranch, a park in-holding, runs about 250 head of cattle, relocated at the park's request from the Pacific Creek allotment slightly north of Elk Ranch. The Elk Ranch pastures provide a safer and more manageable situation for livestock and potential predator-prey conflicts than the unfenced Pacific Creek allotment. The east Elk Ranch pastures are the only park-owned properties that are still irrigated for cattle grazing. The irrigated hay pastures are used not only by cattle but also by bison, elk and other wildlife.

Sometime after taking over the Elk Ranch in 1957, the National Park Service removed the granary/harness shop, barn and one of the combination barn/sheds, and shortened the implement shed. Two of the cabins and the Ferrin dwelling were removed or destroyed and the Ferrin wood shed was removed in 1964 (Historical Research Asociates, 1995). The remaining building complex of Elk Ranch remains mainly unused. The shop is used for irrigation materials and equipment. The corrals and barn were last used in 2000. The reservoir, dam and irrigation system remain in use to provide water to the hay meadows.

\section{Irrigation history}

Of all the activities on the Elk Ranch, irrigation was and continues to be the most important. The Buffalo Bench is a fertile area but without water it would not be nearly as productive. Every steward of the Elk Ranch has recognized the importance of irrigation from the earliest settler to the modern day Park Service. The birth and growth of the irrigation system can be traced from prior to 1897 to the present.

The earliest indication of a ditch being built on the Elk Ranch is mentioned by Marion V. Allen in his book Early Jackson Hole. Allen refers to a ditch on the Buffalo Bench that had been dug by miners prior to 1897 "through Spread Creek draw, almost to the Uhl hill, then down to the Snake River where they tried mining and apparently failed" (Allen, 1981). A hand drawn 1897 map titled "Plat of the Wolff Ditch" confirms the location of this ditch (Wyoming Water Rights Database "Plat of the Wolf Ditch", 1897). The map shows irrigation ditches branching off of Wolff Ditch that were later extended to cover the Elk Ranch. These two sources show that an irrigation system already existed in the Elk Ranch area when Otto Kusche and Si Ferrin homesteaded on the Buffalo Bench in the first decade of the $20^{\text {th }}$ century (Figure 7).

In 1940, the Snake River Land Company built Uhl Reservoir in order to shore up the water supplies for irrigating the Elk Ranch. The construction of the reservoir was part of a significant investment in Elk Ranch by the SRLC, once it became clear that the property would play a major role in the future of the park. The company also made improvements to the irrigation system fed by the reservoir.

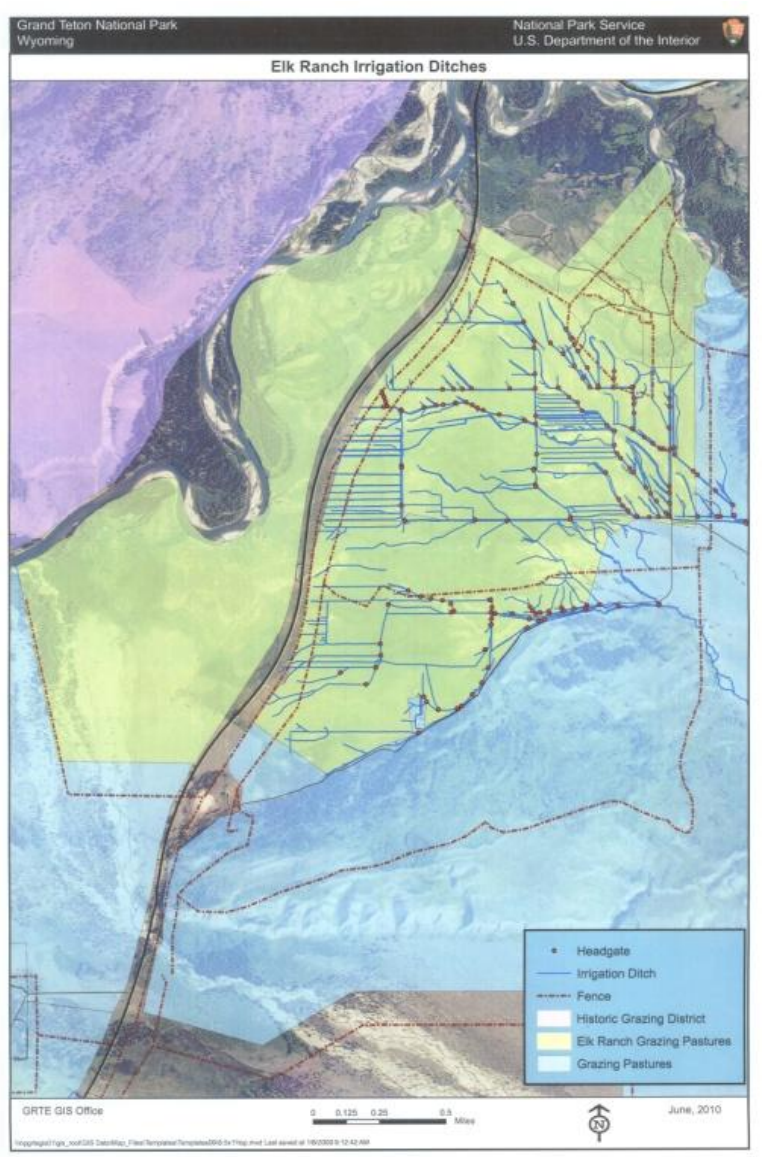

Figure 7. Map of Elk Ranch Irrigation Ditches (National Park Service, 2010). 
Irrigation on the Elk Ranch is achieved through flooding, in which a ditch is dammed at a certain head gate, and water is allowed to build up behind the dam, thus flooding the adjacent pasture. This labor-intensive irrigation, which requires the irrigator to constantly open and close head gates and move dams, still works much the same as it did 100 years ago. Today, plastic tarps are used for damming the ditches. Some original wooden head gates are still in place, while others have been replaced with metal. But overall the original system is still intact.

\section{$\uparrow \quad$ FINDINGS}

In order to be listed on the National Register of Historic Places, a property must have historic significance and integrity - that is, the significance of the property must be evident and understandable (McClelland, 1999). As the sole surviving example of an irrigated cattle and hay ranch in Grand Teton National Park, the Elk Ranch is eligible for the National Register of Historic Places. The property represents the history of land use in the Jackson Hole valley from early $20^{\text {th }}$ century homesteading through the present, encompassing subsistence agriculture, hay raising, cattle grazing and recreation/park use. When the property was homesteaded by Otto Kusche in 1909, it was one of many small ranches occupying the flat lands in the Buffalo Fork -Spread Creek area. Under subsequent owners the property was consolidated with other nearby ranches, and became one of the largest cattle ranches in the Jackson valley before it was purchased by the Snake River Land Company (SRLC) in 1928. The irrigation system established by the early settlers for their subsistence farming and cattle operations still exists today.

The property is also significant for the role it played in the development of Grand Teton National Park. Recognized for its irrigated pasturelands and local prominence as a cattle ranch, the Elk Ranch was chosen as the headquarters of the SRLC's agricultural operations, and remained important to the company's vision of the future Grand Teton National Park. While most properties purchased by SRLC were cleared of buildings and corrals and returned to their "natural" state, the Elk Ranch was retained because of its excellent hay fields, irrigation system and proximity to the Snake River Land Company's headquarters. J.D. Rockefeller Jr. himself chose to retain Elk Ranch as a working cattle ranch, as a way of "perpetuating the picturesque features of Jackson Hole as a cattle country" (Righter, 1983).
In addition to providing irrigated pasturelands for grazing cattle, Elk Ranch had productive hayfields that supplied hay to neighboring ranches and to the National Elk Refuge. In fact, it was a significant source of hay for the National Elk Refuge from the 1920s through the 1950s.

Because of its prominence and longevity as a cattle ranch, the Elk Ranch has been at the center of the long-ranging conflict over the appropriateness of grazing within the national park. It is the last remaining property upon which cattle graze under permit in the park.

The specific features that contribute to the significance of the Elk Ranch are the location and setting of the ranch itself, which have changed little since the property was homesteaded in 1909; the intricate system of irrigation ditches created by homesteaders and early $20^{\text {th }}$ century cattle ranchers which still functions today in much the same way it did 100 years ago; and the building complex, which remains much the same as it was in the 1940s, when it achieved prominence as the premier cattle ranching property of the Snake River Land Company/Jackson Hole Preserve. Because of the buildings, irrigation ditches, pastures and other landscape features, the site retains the feeling and association of an early $20^{\text {th }}$ century cattle and hay ranch.

\section{$\uparrow \quad$ ACKNOWLEDGEMENTS}

The following University of Wyoming students contributed to this report: Carly-Ann Anderson, Jake Courtney, Kathy Gerlach, Stephanie Lowe, Marit Maidla, Jan Nachtigall, Keith Reynolds, and Sarah Zacharias. The author also acknowledges the help of Andrea Graham, Eric Sandeen and Sophia Beck of the University of Wyoming American Studies Program; Sheila Bricher-Wade of the Wyoming Humanities Council; and Sue ConsoloMurphy, Katherine Longfield and Alice Miller of the National Park Service. NPS intern Betsy Engle provided invaluable research materials from the Rockefeller Archives and provided assistance in use of the Grand Teton National Park Archives, and Bill Lawrence, Elk Ranch irrigator for the National Park Service provided information on the ranch and overall help with the project. In addition to support from the UW-NPS Research Station, this project received funding from Grand Teton National Park.

The most useful primary sources were found in the archives of Grand Teton National Park and the Rockefeller Archives 


\section{Literature Cited}

Allen MV. 1981. Early Jackson Hole. Redding: Press Room Print, 1981.

Daugherty J, Crockett S, Goetzmann WH, Jackson RG. 1999. A Place Called Jackson Hole: The Historic Resource Study of Grand Teton National Park. Moose, Wyoming: Grand Teton National Park, National Park Service.

Edmiston D. 2010. Interview led by Andrea Graham, Marit Maidla, Jake Courtney, and Sarah Zacharias Regarding the Elk Ranch.

Ferrin K. "Tobe Ferrin Tapes: Verbatim Transcriptions from tapes by Harold W. (Tobe) Ferrin." 2002. Jackson Hole Historical Society and Museum, Oral History Collection.

Grand Teton National Park Archives, Real Property Box, Warehouse Cage, box 16, Folder JV 16-32.

Grand Teton National Park Archives, Grazing General File \#1, 1942-1953.

Grand Teton National Park Archives,. Historic Records Collection.

Grand Teton National Park Archives. Photographic Collection.

Historical Research Associates. 1995. Survey, Evaluation, Registration of Historical Resources in GRTE (National Park Service.

How to Apply the National Register Criteria for Evaluation. 1991. National Park Service. Washington, DC: U.S. Government Printing Office.

Hubber A, Caywood J. 1997. Grand Teton National Park Multiple Property Submission. (on file at Wyoming Historic Preservation Office, Cheyenne).

Jackson Hole Historical Society and Museum, Vertical Files, Cattle Ranching and Grazing.

Jackson Hole Historical Society and Museum. Vertical Files, Cattle Ranching, Miscellaneous Ranchers.

Jackson Hole Historical Society and Museum. Photographic Collection.
Kreps B. 2006. Windows to the Past. Jackson: Jackson Hole Historical Society and Museum.

Management plan for buildings listed on the National Register of Historic Places: Grand Teton National Park. 2000. Moose: National Park Service.

Markham J. 1970. "Cattle Ranching in Jackson Hole, Wyoming: The Hatchet and Elk Ranches." Jackson Hole Historical Society and Museum, Vertical Files, Cattle Ranching and Grazing.

McClelland L et al. 1999. National Register Bulletin: Guidelines for Evaluating and Documenting Rural Historic Landscapes. Washington, DC: U.S. Government Printing Office.

Mead B. 2010. Personal interview, Jackson Hole.

Mehls CD. 1987. Grand Teton Historic American Engineering Record Survey (National Park Service, 1987).

Page RR. 1998. Cultural Landscapes Inventory Professional Procedures Guide. Washington, DC: U.S. Department of the Interior, National Park Service.

Righter RW. 1983. Crucible for Conservation: The Creation of Grand Teton National Park. Boulder: Colorado Associated Press.

Rockefeller Archives. 1945. Harold P. Fabian Papers.

Rockefeller Archives. 1950. Jackson Hole Preserve, Inc. Records, Elk Ranch 1950.

Saunders B. 2010. Phone Interview by Sarah Zacharias.

United States Department of the Interior, National Park Service, Grand Teton National Park, "Memorandum from Biologist at Teton National Park to the Superintendent at Teton National Park Regarding Use of Elk Ranch for Permit-Cattle Grazing," March 4, 1955, page 3, Grand Teton National Park Archives, Accession Number 00473, Category Number 48022, Box 10, Folder 100, File $\# 1$.

Water Rights Database. "Water Rights Records, Elk Ranch Area, 1897-1942." http://seo.state. wy.us/wrdb/PS_TnsRngSec.aspx 
Williams OE. 1913. "Certificate of Surveyor, O.K.

Ditch and Homestead of Otto Kusche of Elk, Wyoming." October 18, 1913. Jackson

Hole Historical Society and Museum,

Miller-Fabian Collection, Accession

Number 2010-0014. 